\title{
Economics
}

2018; 7(1): 10-16

$\mathrm{http}: / /$ www.sciencepublishinggroup.com/j/eco

doi: 10.11648/j.eco.20180701.12

ISSN: 2376-659X (Print); ISSN: 2376-6603 (Online)

\section{Developing Orange Fruit Value Chain in Tuyen Quang, Vietnam}

\author{
Tran Thi Dien*, Hoang Anh Dao \\ Faculty of Economics and Business Administration, Tan Trao University, Tuyen Quang, Viet Nam
}

Email address:

tranthidien1979@gmail.com (T. T. Dien)

"Corresponding author

\section{To cite this article:}

Tran Thi Dien, Hoang Anh Dao. Developing Orange Fruit Value Chain in Tuyen Quang, Vietnam. Economics. Vol. 7, No. 1, 2018, pp. 10-16. doi: $10.11648 /$ j.eco. 20180701.12

Received: March 28, 2018; Accepted: April 16, 2018; Published: May 15, 2018

\begin{abstract}
Orange is one of the world's most important economic fruit crops. And in Tuyen Quang, Vietnam, orange is local tree that have been planted for many generations. The study analyzed the supply chain and the value chain of orange in Tuyen Quang, compared to the supply chain and the orange value chain in industrialized nations, and have seen that the the orange value chain in the province has not developed yet. All products are consumed as fresh fruits, without processing of products from orange. Consumption of orange fruit is only in the domestic market, no export activities. The linkages between the actors in the chain have not been deep and inefficient. Harvest and transport fresh fruit was mostly done by hand. Preservation, packaging, refrigeration and processing activities have not been implemented. These lead to high post-harvest losses and selling of orange fruit is still difficult and seasonal. SWOT analysis was used too, and some strategic solutions were identified to develop the orange value chain.
\end{abstract}

Keywords: Developing, Orange Fruit, Value Chain, Tuyen Quang

\section{Introduction}

The sequence of steps and participants involved in the process from production to delivery of a product to market is called a value chain. Value chains are organized linkages between groups of producers, traders, processors, and service providers that join together to improve productivity and the value added of their activities. By joining together, the participants in a value chain increase competitiveness and are better able to maintain competitiveness through innovation [1]. The limitations of each single participant in the chain are overcome by establishing cooperation and governance rules aimed at producing higher value. The main advantages to stakeholders from being part of an effective value chain include being able to reduce the costs of production and business; increase revenues; increase bargaining power; improve access to technology, information, and capital; and, by doing so, innovate production and marketing processes to gain higher value and provide higher quality to customers. Value chain development for sustainable agriculture aims to improve the overall natural sustainability of the entire chain by optimizing links between actors. At every stage efforts focus on rationalizing the natural inputs into the value chain and controlling the outputs affecting the natural environment. In relation to inputs, this includes improving efficiency and renewable capacity in terms of water, energy, material, building, land and tools. In relation to outputs, the approach focuses on wastage and pollution, drawing on methods of pollution control, cleaner production, eco-efficiency, life cycle assessment, closed loop production and industrial ecology.

Orange is one of the world's most important economic fruit crops. It belongs to the group of citrus fruits that includes orange, lemon, limes, grape fruits and tangerines. In the world, a third of orange fruit production goes for processing, the rest being eaten fresh. Also the most important processed citrus product is orange juice, representing about $80 \%$ of the total citrus juice production. In the orange processing industry, the raw juice constituting about $50 \%$ of the processed fruit, the peel residue and the seeds are the major products or by-products and from these sources a lot of industrial products are derivable. For example, natural orange juice, concentrated juice, orange 
flour are some of the major industrial products derived from the raw juice. Also, the pressed peel, orange pulp and meal, peel oil, citric and lactic acids, brandy spirit, feed yeast, vinegar, marmalade and candied peel are products derivable from peel residue. Products derivable from the seeds are seed oil and meal [2]. The leaves, flowers, peels, fruits and dried bark of orange have important medicinal values. The dried bark of orange is a raw material for the production of insecticides. Orange has also found use in the pharmaceutical, cosmetic and soap industries. Farm inputs (nurseries, fertilizers and agro chemicals) are at the bottom of the orange value chain with end points in large processing and exporting companies and the domestic market [3]. Major actors in the value chain for industrialized nations include farmers and commercial orchard owners, citrus pickers, local fruit marketers and exporters, citrus processing factories, industries that engage in the utilization of by-products for the production of specialty products.

Tuyen Quang is a mountainous province in the Northwest of Vietnam, dominated by agro-forestry economy, with an area of 586,733ha, in which agricultural and forestry land accounted for $90.5 \%$. The province has natural and socialeconomic conditions advantageous and suitable to produce some agriculture products, especially orange [4]. Orange are fruit with high nutritional value, beneficial to health. In addition to the common use as a food and beverage, orange have many healing effects. Orange are local trees that have been planted for many generations in Ham Yen and Chiem Hoa districts, and have many strengths for the province, with high economic value, bringing high and stable income for local people, helping reduce poverty, providing many jobs for rural workers and contributing to the development of Tuyen Quang's economy. By 2015, the province's orange cultivated areas reached 7,242 hectares, the area for harvesting is 3,715 hectares, the output reached 50,513 tons/year, with 4,215 orange growers [5]. Development of orange value chain for sustainable agriculture will bring great economic values for the province as it can bring high and stable income for local people, help reduce poverty, provide jobs for rural workers, supply good quality orange products to consumers, effectively use economic resources, protect the environment and preserve biodiversity. Based on the views and aims of development of product value chain for sustainable agriculture, the study assessed status of orange fruit production and marketing and propose solutions for development of orange fruit value chain in Tuyen Quang province, Vietnam.

\section{Methods of the Study}

This study uses descriptive statistics and value chain analysis methods to assess the orange value chain of the growers, and financial analysis is used to analyze the chain economy. Data for the study were collected using questionnaires from stakeholders in the orange value chain in Tuyen Quang province. The data was also collected by the Participatory Rural Appraisal (PRA) interview method of many stakeholders. Agricultural production involves a number of actors at different stages. Identifying and evaluating the relationships as well as the impact of these actors is essential to build a strategy for developing the industry [6]. The information collected includes: Cost of production of orange; productivity, quantity and selling price of orange; market channels... The SWOT method was also used to analyze strengths, weaknesses, opportunities and challenges in the production and marketing of orange, thereby proposing strategic solutions to develop the orange value chain in Tuyen Quang province. There are different actors performing various functions in the fresh orange sub sector. On its way from soil to plate, the orange fruit passes through the hands of several actors [7]. This study employed a sample size of 208 respondents. A simple random sampling technique was used to select growers and consumers, and while purposive sampling technique was used to select key informants such as local officials, experts for this study. Key informants were selected base on their positions and ability to provide the required information from the district, commune, and village levels. Moreover, we employed purposive sampling technique because the study was interested in interviewing respondents who were knowledgeablea and experienced and who could provide accurate information concerning this study.

Table 1. Stakeholders and method of collecting information.

\begin{tabular}{llll}
\hline No & Stakeholders & $\begin{array}{l}\text { Number of } \\
\text { samples }\end{array}$ & $\begin{array}{l}\text { Method of } \\
\text { collection }\end{array}$ \\
\hline 1 & Suppliers & 5 & Questionnaires \\
2 & Growers & 120 & Questionnaires \\
3 & Collectors & 10 & Questionnaires \\
4 & Wholesalers & 10 & Questionnaires \\
5 & Retailers & 20 & Questionnaires \\
6 & Consumers & 30 & Questionnaires \\
7 & Local officials & 5 & Interview \\
8 & Agricultural economists & 3 & Interview \\
& Total & 208 & \\
\hline
\end{tabular}

(Source: Survey data, 2016)

\section{Results and Discussions}

\subsection{Technical Appraisal of Orange Value Chain}

\subsubsection{Orange Supply Chain}

In the orange supply chain, harvested fruit may go to the fresh fruit market, in order to be consumed fresh, or squeezed freshly at home to be consumed as juice, or it may enter the processing industry, in order to obtain orange juice (mainly in the form of frozen concentrated orange juice, for ease of transport in international trade) and other by-products. Orange supply chain for industrialized nations is shown in figure $1[8]$ : 


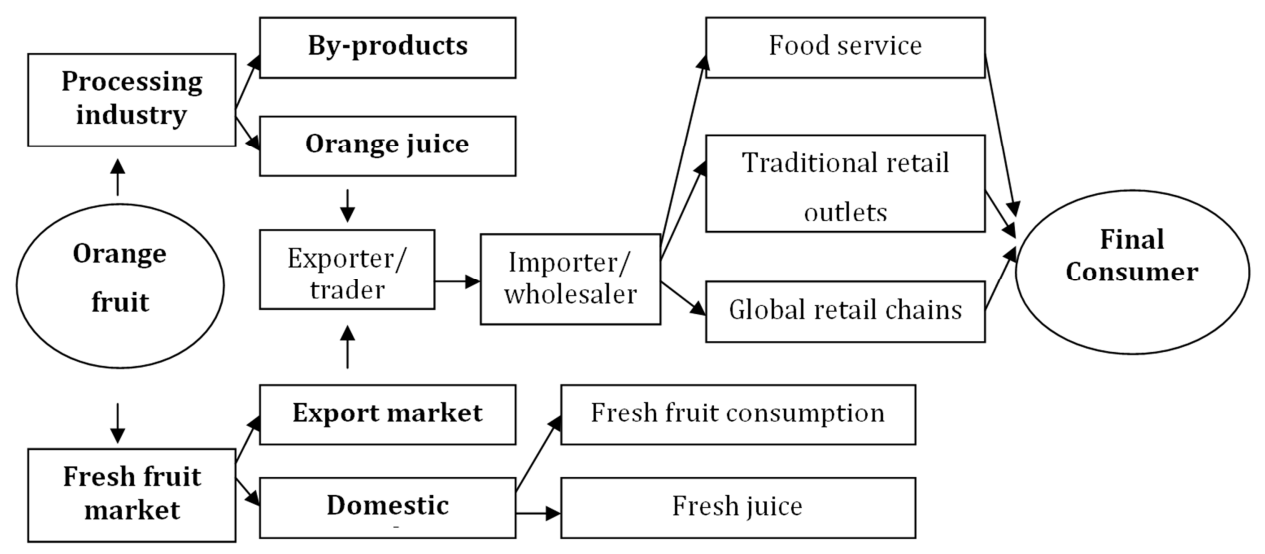

Figure 1. Orange Supply Chain in industrialized Nations.

In Tuyen Quang, however the supply chain is poorly developed and disorganized requiring improvement for investment opportunities to spin off. The results of the orange supply chain study in Tuyen Quang show that the stakeholders in the channel system include: farmers; collectors, traders and agricultural cooperatives; Retailers; and Consumers. The sale of products has not yet signed sale contracts. There is no joint venture between producers and enterprises. The products of the supply chain mainly sell fresh fruit directly to domestic consumers without processing and exporting.

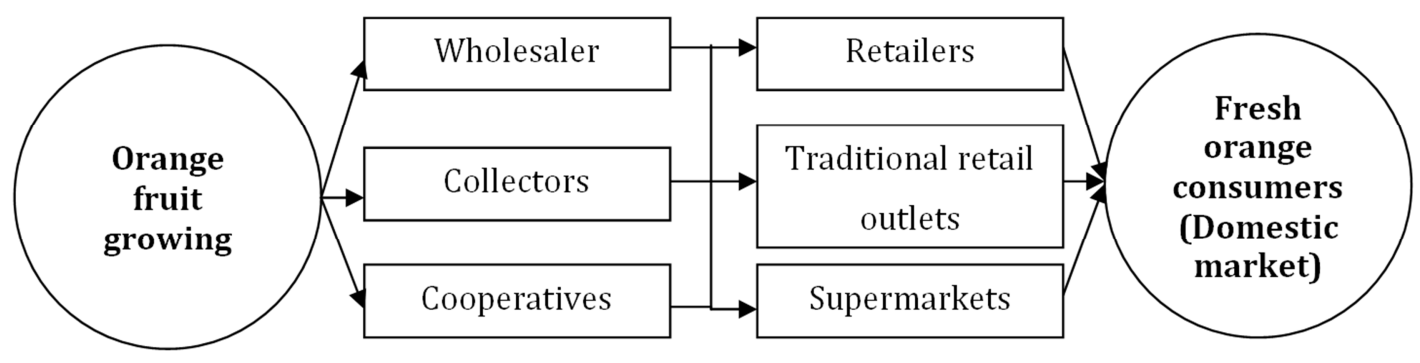

(Source: Synthesis from surveys, 2016)

Figure 2. Orange supply chain in Tuyen Quang, Vietnam.

\subsubsection{Orange Value Chain}

Farm inputs (nurseries, fertilizers and agro chemicals) are at the bottom of the citrus value chain with end points in large processing and exporting companies and the local domestic market (figure 3). Major actors in the value chain for industrialized nations include farmers and commercial orchard owners, citrus pickers, local fruit marketers and exporters, citrus processing factories, industries that engage in the utilization of by-products for the production of specialty products [3].

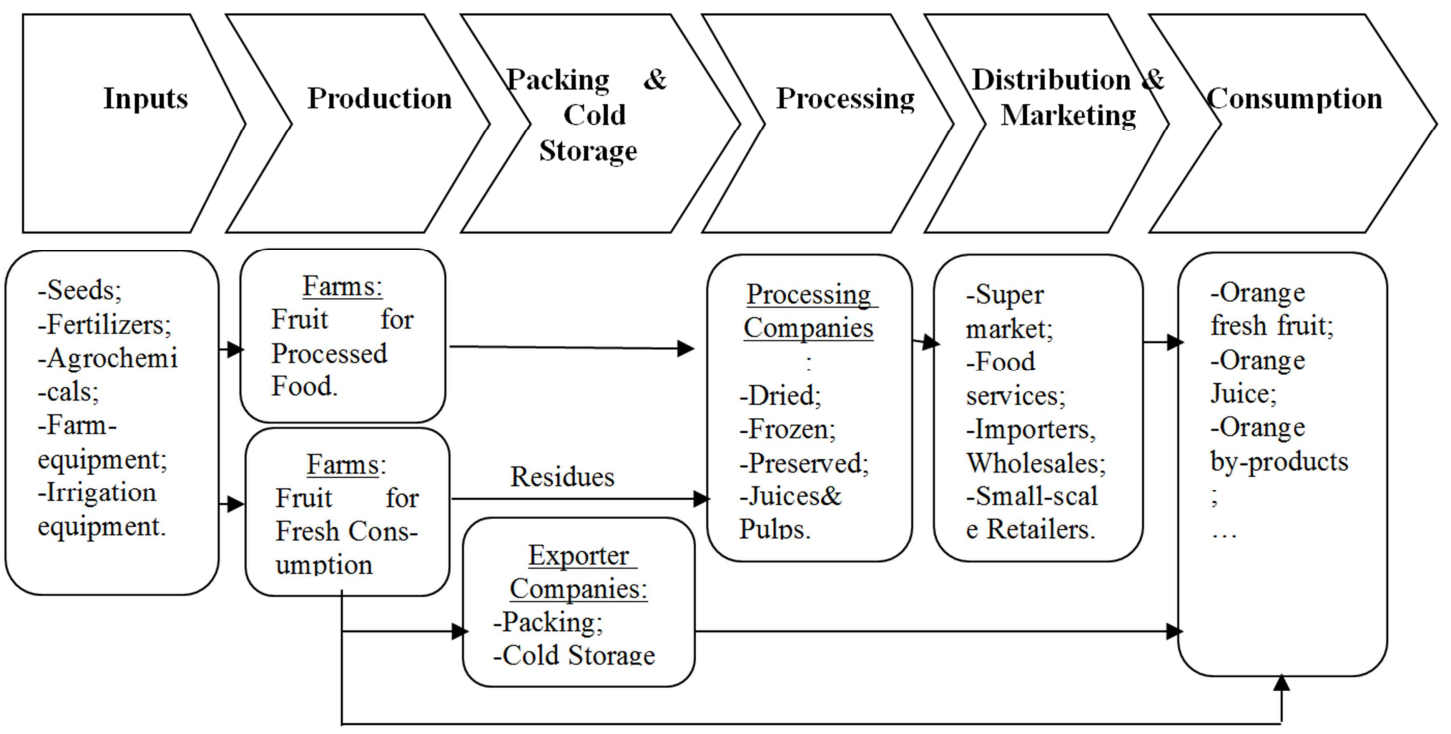

Figure 3. Citrus fruit value chain in industrialized nations. 
But the orange value chain in Tuyen Quang is not developed (figure 4). Farm inputs are at the bottom of the value chain with end point in domestic fresh fruit market. Major actors include family orchard owners, local collectors, traders, retaiers and domestic consumers. Concentrate production is not well developed in the province judging by

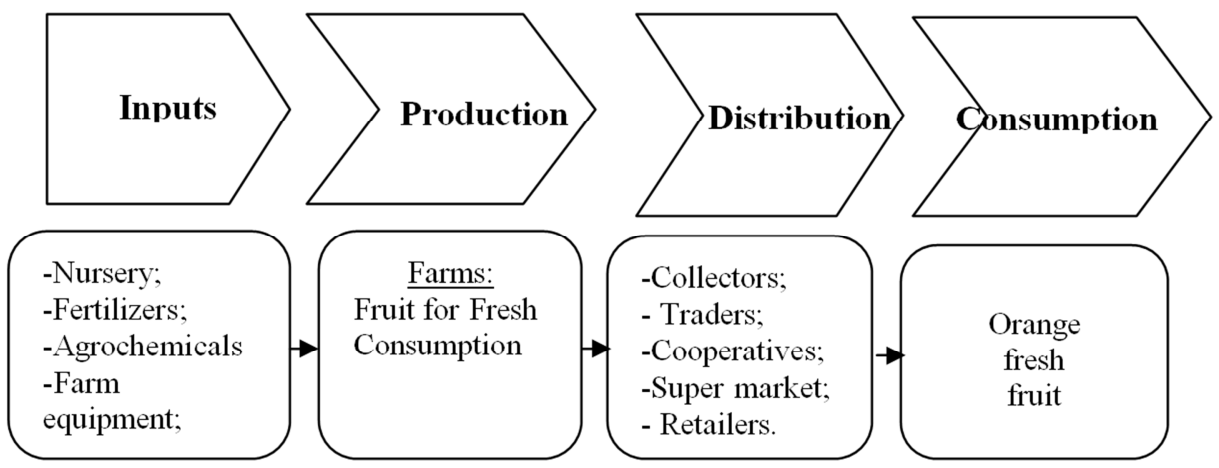

(Source: Synthesis from surveys, 2016) the fact that there isn't any concentrate plant. Investment of resources for production and business is small scale and scattered. Inadequate investment of infrastructure systems, machinery and equipment, including production, harvesting and processing technologies, which lead to low value of orange.

Figure 4. Citrus Fruit Value Chain in Tuyen Quang, Vietnam

There are no packing and cold storage facilities for fruits in Tuyen Quang. The transportation from farms to the market is crude. The availability of fruits is short-lived due to their seasonal and highly perishable nature. Almost of the orange are consumed directly as they came from the orchard. The production and harvesting of orange is still by hand, spontaneous and highly seasonal:Many stages of the production process are executed manually, with insufficient investment, and production significantly influenced by natural factors [9]. Therefore labor productivity is not high, with uneven performance and year-season or year- crop failure, leading to difficulty contracting with enterprises which process, transport, sell and export such agricultural products. The expansion of households' orange growing areas was spontaneous, so brought with it many risks. The harvest of fresh fruit has been seasonal (from October of one year to February the next year), while the preservation and processing of orange remains undeveloped. As a consequence, the consumption of the product is also highly seasonal.

\subsubsection{Value Added of the Orange Value Chain in Tuyen Quang Province}

Table 2. Cost of production of orange (Calculated for 1ha/year).

\begin{tabular}{lll}
\hline Calculated criteria & Value (1000VND) & \% of Total \\
\hline Cost of Materials & 35,097 & 45.09 \\
Organic fertilizer & 7,706 & 9.90 \\
Nitrogen & 3,554 & 4.57 \\
Potassium & 2,379 & 3.06 \\
Phosphorus & 3,785 & 4.86 \\
Insecticide & 16,679 & 21.43 \\
Herbicide & 661 & 0.85 \\
Fungicide & 333 & 0.43 \\
Cost of Labor & 32,580 & 41.86 \\
Spraying pesticides & 16,480 & 21.17 \\
Manure & 1,033 & 1.33 \\
\hline
\end{tabular}

\begin{tabular}{lll}
\hline Calculated criteria & Value (1000VND) & \% of Total \\
\hline Hand weeding & 2,098 & 2.70 \\
Spray herbicide & 1,577 & 2.03 \\
Pruning, creating canopy & 893 & 1.15 \\
Harvest -Pick \& Haul & 10,499 & 13.49 \\
Cost of Depreciation & 10,155 & 13.05 \\
Orchard Establishment & 9,022 & 11.59 \\
Machineries and tools & 1,133 & 1.46 \\
Total Cost & 77,832 & 100.00 \\
\hline
\end{tabular}

(Source: Calculated from survey data in 2016)

Table 3. Economic indicators of the orange growers.

\begin{tabular}{llll}
\hline No & Culculators & Unit & Value \\
\hline I & Production results & & \\
1 & Average productivity & Kg/ha & 21,530 \\
2 & Average selling price & VND/kg & 9,300 \\
3 & Gross of Output (GO) & VND & $200,229,000$ \\
4 & Intermediate Cost (IC) & VND & $45,252,020$ \\
5 & Labor Cost (LC) & VND & $32,579,930$ \\
6 & Total Cost (TC =IC + LC) & VND & $77,831,950$ \\
7 & Value Added (VA) & VND & $154,976,980$ \\
8 & Mixed Income (MI) & VND & $77,145,030$ \\
II & Economic efficiency & & \\
1 & GO / IC & times & 4.42 \\
2 & VA / IC & times & 3.42 \\
3 & MI / IC & times & 1.70 \\
\hline
\end{tabular}

(Source: Calculated from survey data in 2016)

Based on the actual survey of orange consumption channels in Tuyen Quang province in 2016, 9.8\% of the orange were consumed locally with the average retail price of $12,800 \mathrm{VND} / \mathrm{kg}$. Compared to the orchards's average selling price of $9,300 \mathrm{VND} / \mathrm{kg}$, the first channel (Orange grower -> Local retailer) generated added value of $3,500 \mathrm{VND} / \mathrm{kg}$. The output of orange consumed in Hanoi city and the Northern provinces was $27.3 \%$, in the Central provinces $18.8 \%$, and in Ho Chi Minh city and the Southern provinces was $44.1 \%$. This indicates that the largest market for Tuyen Quang's 
orange is Ho Chi Minh City and the Southern provinces, with the average retail price paid by consumers is $28,600 \mathrm{VND} / \mathrm{kg}$.
Compared to the production cost, it generated by this distribution channel is $19,300 \mathrm{VND} / \mathrm{kg}$.

Table 4. Value added of the main market channels of the orange value chain.

\begin{tabular}{|c|c|c|c|c|}
\hline Distribution channels & Distance (km) & $\begin{array}{l}\text { Market share } \\
(\%)\end{array}$ & $\begin{array}{l}\text { Average } \\
\text { selling price }\end{array}$ & Added value \\
\hline Growers (at the farm gate) & 0 & 100 & 9,300 & 5,685 \\
\hline Growers -> Local retailer & 55 & 9.8 & 12,800 & 3,500 \\
\hline Growers $->$ Wholesalers $->$ Retailers in Hanoi and Northern provinces & 165 & 27.3 & 17,700 & 8,400 \\
\hline Growers -> Wholesalers -> Retailers in Central provinces & 928 & 18.8 & 24,300 & 15,000 \\
\hline Growers $->$ Wholesalers $->$ Retailers in HCM city and Southern provinces & 1875 & 44.1 & 28,600 & 19,300 \\
\hline Average & 1052 & $\mathrm{x}$ & 22,013 & 12,713 \\
\hline
\end{tabular}

(Source: Calculated from survey data in 2016)

Accounting the surveyed growers's cost of production shows that the average production cost was $3.615 \mathrm{VND} / \mathrm{kg}$. The average selling price of the surveyed growers was 9,300 $\mathrm{VND} / \mathrm{kg}$, so the added value generated by the growers was $5,685 \mathrm{VND} / \mathrm{kg}$, account for $25.8 \%$ of the average selling price in the market. Table 4 shows that the average retail price in the market for final consumers was $22,013 \mathrm{VND} / \mathrm{kg}$, thus the added value generated by the traders was 12,713 $\mathrm{VND} / \mathrm{kg}$, account for $58 \%$ of the selling price. Value added in the orange value chain is illustrated in Figure 5.

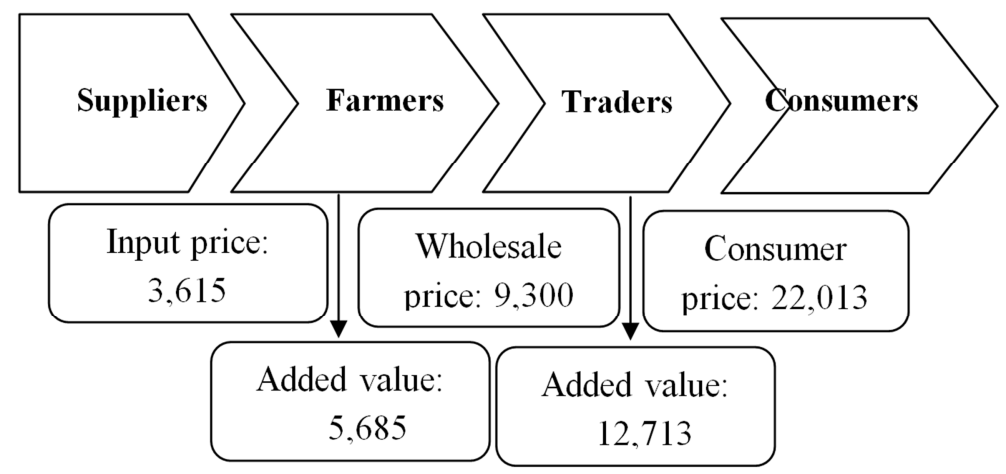

(Source: Calculated from collected data in 2016)

Figure 5. Value added in the fresh orange value chain (unit:VND/kg).

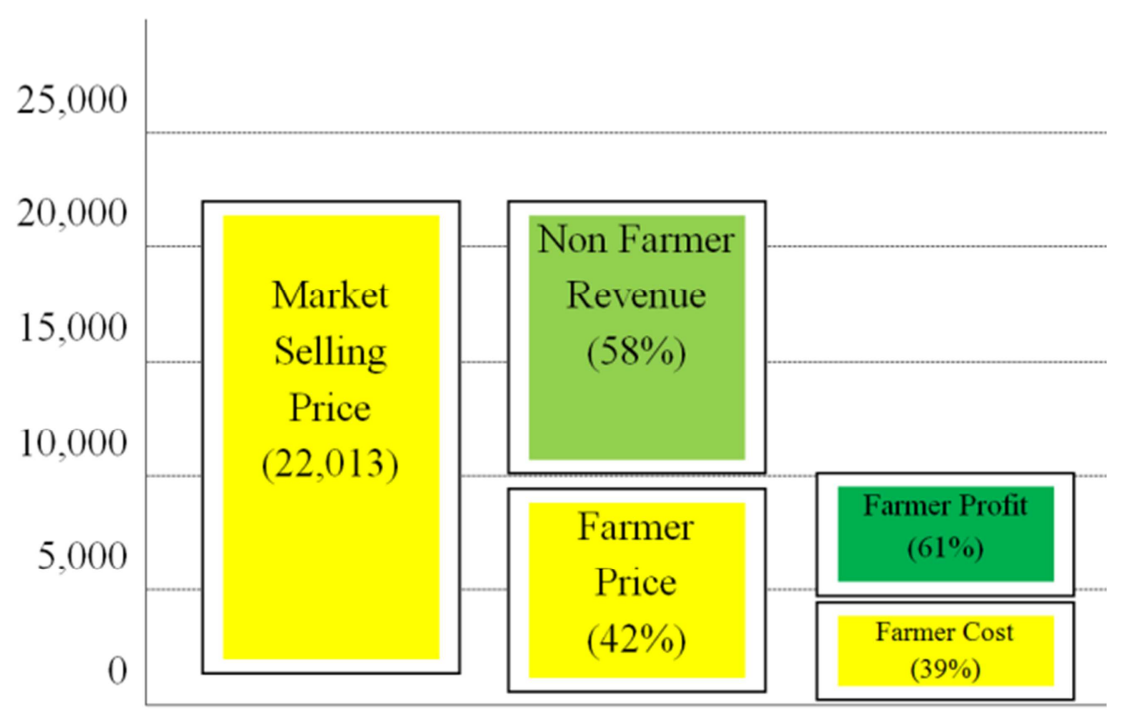

Figure 6. Farmer Profit for Orange fruit in Tuyen Quang (unit:VND/kg).

The production cost is $3,615 \mathrm{VND} / \mathrm{kg}$, accounting for $39 \%$, the grower's profit is $5,685 \mathrm{VND} / \mathrm{kg}$, accounting for $61 \%$ of the selling price $(9,300 \mathrm{VND} / \mathrm{kg})$. This data shows that orange growers in Tuyen Quang province have achieved a high profit margin of $157 \%$. The production cost for $1 \mathrm{~kg}$ of orange in Tuyen Quang is low due to the availability of soil, water, and climate. Therefore, although the investment cost is low, orange trees still produce high productivity and yield. On the other hand, Ham Yen Orange have good quality and well-known brand, so consumers are willing to pay high prices, sometimes at the end of seasons, the consumer price up to $50,000 \mathrm{VND} / \mathrm{kg}[10]$. However, this data shows that the 
traders's cost and profit are higher than the growers's production cost and profit $(3.615+5.685=9.300 \mathrm{VND} / \mathrm{kg})$. Consumers have paid much higher than production costs $(22,013 / 3,615=6.1$ times $)$. This also shows weakness in circulation and distribution as high rate of rotten products and losses. The competition among subjects in intermediate stages is not high. And the linkage in the production and consumption of orange industry is inefficient.

\subsection{SWOT Analysis and Strategic Solutions for Development the Orange Value Chain}

By analyzing the market and value chain of Tuyen Quang's orange, the following table summarizes the strengths, weaknesses, opportunities and threats of the orange value chain and strategic solutions for upgrading the orange value chain in the coming time.

Table 5. SWOT Analysis of Orange Value Chain in Tuyen Quang, Vietnam.

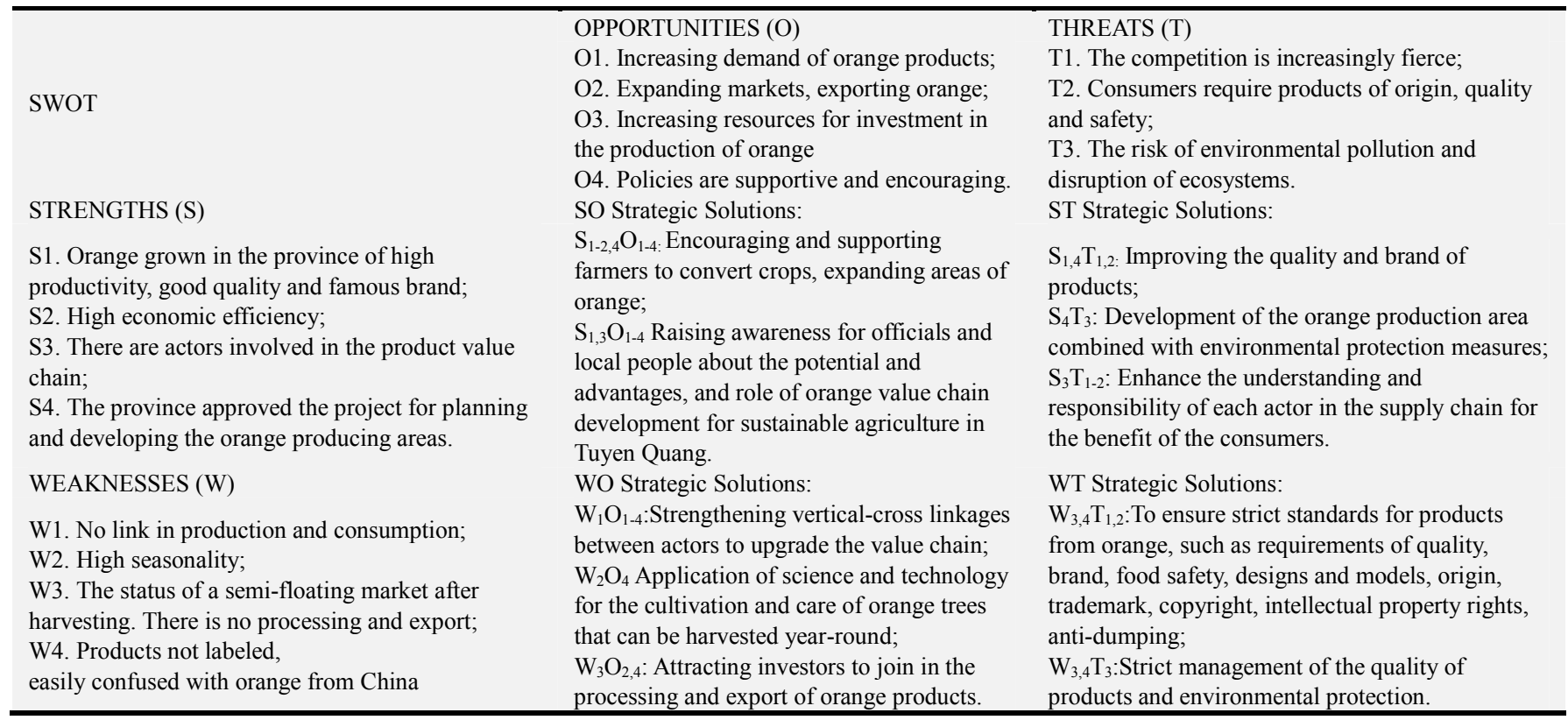

(Source: Synthesis from surveys, 2016)

\section{Conclusions}

The analysis shows that Tuyen Quang has many advantages for the development of orange production. The province has suitable land and climate conditions; the orange growing area is large (7,242ha); many households involved in orange production (4,215 growers); local people have experienced growing orange for many generations; productivity and orange fruit quality are good. However, the process of developing the orange value chain is inefficient and faces many difficulties, such as: the orange value chain in Tuyen Quang has not developed yet. The product is completely consumed in the form of fresh fruit, without processing of products from orange. Marketing of orange fruit is almost in the domestic market, no export activities. The linkages between the actors in the chain value has not been deep and ineffective. Harvesting and transportation of fresh fruit is handmade. Preservation, packaging, refrigeration and processing activities have not been implemented. These lead to high post-harvest losses and selling of orange fruit is still difficult and seasonal. The solutions to develop the orange value chain were identified, which are: Continuing to develop production of oragnes; Planning projects for the development of orange value chain; Overcoming the seasonality of orange production; Increasing investment of resources for orange production; Strict management of the quality of products and environmental protection; Diversification of products and expansion of the market for orange; Human resource training; Implemention of policies to support the orange growers; Capacity building of the orchard owners. The solutions should be implemented in a coordinated and effective way to develop the orange value chain in Tuyen Quang, Vietnam.

\section{References}

[1] F. Goletti.(2004). Commercialization, Value Chains, and Poverty Reduction, Markets for the Poor, Phase 1. Agrifood Consulting International.

[2] Olife, I. C, Ibeagha, O. A, Onwualu, A. P., (2015). Citrus Fruits Value Chain Development in Nigeria. Journal of Biology, Agriculture and Healthcare, ISSN 2225-093X, Vol. 5, No. 4, 2015.

[3] Karina, F., Penny B., Gary G., (2011). The Fruit and Vegetables Global Value Chain; Economic Upgrading and Workforce Development. Center on Globalization, Governance \& Competitiveness, Duke University.

[4] Hoang Thanh Van, Tran Viet Khanh. (2015). Natural conditions and resources affect socio-economic development in Tuyen Quang province. Journal of Science \& Technology, 65 (03): 39-43. 
[5] Tuyen Quang Statistic Department.(2016). Tuyen Quang Statistic Book 2015. Hanoi Statistic Publisher.

[6] Zhang, X. and Aramyan, L. H. (2009) "A conceptual framework for supply chain governance: An application to agri-food chains in China", China Agricultural Economic Review, Vol. 1 No. 2, pp. 136-154.

[7] Robert Makorere.(2014). An exploration of factors affecting development of citrus industry in Tanzania: empirical evidence from Muheza district, Tanga region. International Journal of Food and Agricultural Economics ISSN 2147-8988 Vol. 2 No. 2 pp. 135-154.
[8] UNCTAD, (2007). Market Information in the Commodities Area: Citrus Fruit.

[9] Tuyen Quang Department of Agriculture and Rural Development (DARD). Report on the development of citrus in Tuyen Quang province, 2016.

[10] Tuyen Quang Department of Agriculture and Rural Development (DARD).(2015). Report on the situation of agriculture and forestry production in 2010-2015. 